\title{
Changes in UV penetration associated with marine intrusions and freshwater discharge in a shallow coastal lagoon of the Southern Atlantic Ocean
}

\author{
D. Conde ${ }^{1}$, L. Aubriot ${ }^{1}$, R. Sommaruga ${ }^{2, *}$ \\ ${ }^{1}$ Limnology Section, Faculty of Sciences, University of Uruguay, Iguá 4225, 11400 Montevideo, Uruguay \\ ${ }^{2}$ Institute of Zoology and Limnology, University of Innsbruck, Technikerstr. 25, 6020 Innsbruck, Austria
}

\begin{abstract}
We studied the changes in UV penetration associated with the dynamics of a shallow (mean depth $=0.6 \mathrm{~m}$ ) coastal lagoon of South America that communicates periodically with the Atlantic Ocean. Two characteristic situations, i.e., freshwater dominance and salt-wedge intrusion were considered. Nine stations were sampled along the main axis of the lagoon, the main tributary, and the adjacent coast. The attenuation in the UV-B, UV-A and PAR wavebands were related to changes in the concentration of dissolved organic carbon (DOC), chlorophyll a (chl a), absorption $\left(a_{\mathrm{d}}\right)$ of the chromophoric dissolved organic matter $(\mathrm{CDOM})$, fluorescence of CDOM $\left(F_{\mathrm{d}}\right)$, organic (OSS) and inorganic (ISS) suspended solids. The area most influenced by the marine intrusion showed the lowest DOC concentration $\left(1.8 \mathrm{mg} \mathrm{l}^{-1}\right)$ and the highest UV penetration. In this area, the depth corresponding to $10 \%$ of the irradiance below the surface $\left(Z_{10 \%}\right)$ accounted for 66 and $100 \%$ of the water column for the UV-B and UV-A wavebands, respectively (diffuse attenuation coefficient, $K_{\mathrm{d}}=7.3$ and $2.1 \mathrm{~m}^{-1}$ ). The other zones of the lagoon (DOC $=5.7$ to $9.3 \mathrm{mg} \mathrm{l}^{-1}$ ) presented low UV-B penetration $\left(K_{\mathrm{d}}=29\right.$ to $\left.64 \mathrm{~m}^{-1}\right)$, and the $Z_{10}$ for UV-A accounted for 30 to $64 \%$ of the water column $\left(K_{\mathrm{d}}=7\right.$ to $\left.14 \mathrm{~m}^{-1}\right)$. Under both hydrological situations, the $Z_{10}$ for PAR reached the bottom in most parts of the lagoon $\left(K_{\mathrm{d}}=1\right.$ to $\left.5 \mathrm{~m}^{-1}\right)$. A significant reduction in DOC-specific absorption $\left(a_{\mathrm{d}}{ }^{*}\right)$ during the marine intrusion indicated a change in the absorption characteristics of the CDOM. The variability in $K_{\mathrm{d}}$ for UV-B radiation was mainly explained by the concentration of dissolved and particulate organic substances, while the $K_{\mathrm{d}}$ values for UV-A and PAR were best predicted by the concentration of DOC and chl $a$.
\end{abstract}

KEY WORDS: Ultraviolet radiation · UV-B · Dissolved organic carbon · Chromophoric dissolved organic matter $\cdot$ Fluorescence $\cdot$ Estuaries $\cdot$ ENSO

\section{INTRODUCTION}

Several lake surveys have shown that the variability in UV attenuation among systems can be explained by changes in the concentration of dissolved organic carbon (DOC) or in optical characteristics (e.g., absorption and fluorescence) of the chromophoric dissolved organic matter, CDOM (Scully \& Lean 1994, Morris et al. 1995, Laurion et al. 1997). In addition, absorption and scattering by biogenic or minerogenic particles have been indicated to contribute to the UV attenua-

${ }^{*}$ Corresponding author. E-mail: ruben.sommaruga.uibk.ac.at tion in several aquatic systems (Piazena \& Häder 1994, Sommaruga \& Psenner 1997, Hodoki \& Watanabe 1998, Smith et al. 1999).

Despite the ecological relevance of estuaries and other shallow brackish systems such as coastal lagoons, relatively few studies have been devoted to revealing the factors that control the UV attenuation in these ecosystems (Piazena \& Häder 1994, Kuhn et al. 1999). Even less is known about the temporal and spatial dynamics of UV attenuation as affected by the mixing of marine and freshwaters. The mixing of water masses during marine intrusion produces strong shifts in turbidity, as well as in chlorophyll $a(\mathrm{chl} a)$ and DOC con- 


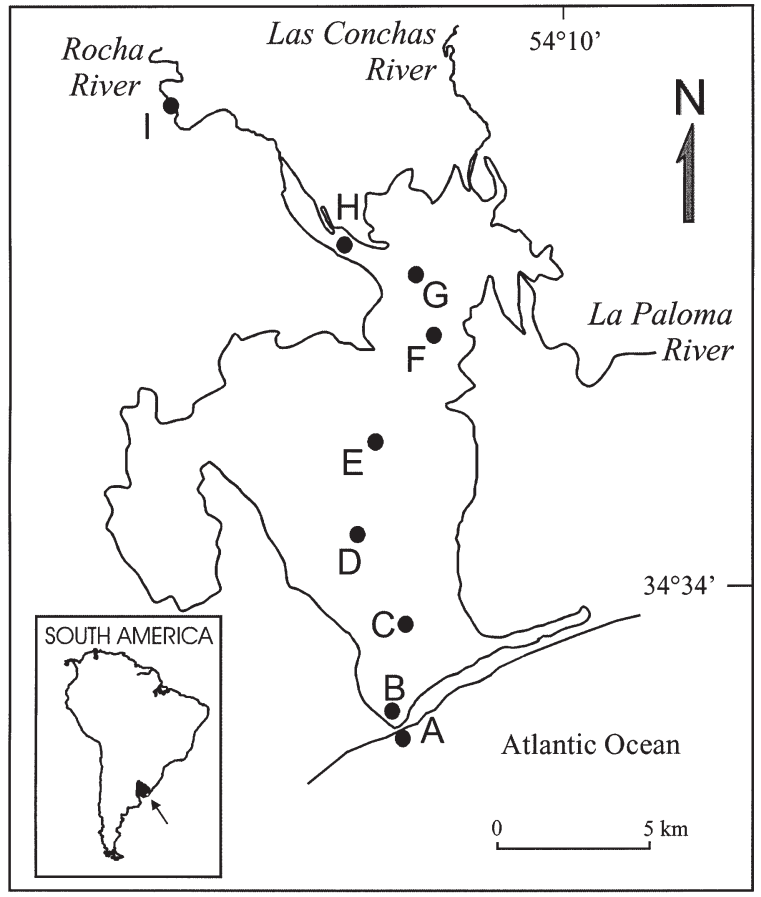

Fig. 1. Location of Laguna de Rocha and sampling stations

centrations, while at times of high freshwater discharge the water transparency is more homogeneous (Cowan \& Boyton 1996).

Shallow lagoons from the eastern coast of South America are particularly susceptible to changes in UV underwater climate and its ecological impact, since they are located at latitudes where significant trends in depletion of stratospheric ozone are expected over the next decades (Sze et al. 1989). In addition, site-specific ozone reductions have been reported over South America as far as $30^{\circ} \mathrm{S}$ as a consequence of the transport of air masses with low ozone concentrations after the break-up of the Antarctic vortex circulation (Kirchhoff et al. 1996, Orce \& Helbling 1997). Another important characteristic of aquatic systems in South America is the tight coupling of the rainfall pattern and El NiñoSouthern Oscillation, ENSO (Mechoso \& Perez-Iribarren 1992). Changes in the CDOM export from the catchment related to droughts or excessive rainfall events may be even more important for the underwater UV-B climate than changes in stratospheric ozone concentration (Williamson et al. 1996, Vincent et al. 1998).

The aims of this study were to investigate the changes in UV penetration and underwater optical characteristics associated with the dynamics of a shallow coastal lagoon of South America that communicates periodically with the Atlantic Ocean and to identify the main attenuating factors.

\section{MATERIALS AND METHODS}

Study area. Laguna de Rocha is a shallow and large brackish lagoon (mean depth $=0.6 \mathrm{~m}$; area $=72 \mathrm{~km}^{2}$ ) located on the southeastern coast of South America $\left(34^{\circ} 33^{\prime} \mathrm{S}, 54^{\circ} 22^{\prime} \mathrm{W}\right.$; Fig. 1) and forming part of a MaB/UNESCO Biosphere Reserve. The basin of the system extends over $1312 \mathrm{~km}^{2}$ and is drained by 3 rivers, of which the most important in terms of flow is River Rocha (Fig. 1). Marshes of Schoenoplectus (Scirpus) californicus and areas covered by Potamogeton sp. and Cabomba sp. are commonly found close to the freshwater end of the system, dominated by finegrained sediments with an organic content of 2 to $4 \%$ (Conde \& Sommaruga 1999). Sandy sediments containing less than $1 \%$ of organic matter are dominant at the southern area of the lagoon. The lagoon is an area of nursery and feeding for crustaceans and fishes of great economical value such as Penaeus paulensis (shrimp), Callinectes sapidus (blue crab), and Micropogonias furnieri (croacker). Relevant limnological information about the system has been published elsewhere (Conde \& Sommaruga 1999, Conde et al. 1999).

The lagoon is separated from the sea by a sand bar that opens naturally through a single mouth when the water level increases above $\sim 1.3 \mathrm{~m}$ (choked-type). However, opening of the lagoon only takes place when a combination of thixotrophy and high wave action on the seaward side of the sandbar occurs (e.g., during storms). Intercommunication with the ocean may occur several times per year, and the water discharge of the lagoon during such events may reach up to $570 \mathrm{~m}^{3} \mathrm{~s}^{-1}$ (Conde \& Sommaruga 1999). After the freshwater discharge, marine intrusion takes place. Aerial views of the closed and open situations can be obtained at http://zoology.uibk.ac.at/limno/images/rocha.html.

Sampling. Two sampling periods representing extreme hydrological situations were selected: a period of marine intrusion (March 11 to 13, 1997) and a period of freshwater dominance (February 27 to March 1, 1998, when the lagoon was isolated from the ocean). A transect of 9 stations was set up (Fig. 1): 7 stations in the lagoon, 1 in the main tributary, and 1 in the adjacent coastal area. All fieldwork was done from an anchored rubber boat, taking care to avoid resuspension of the sediments (the anchor was released ca $20 \mathrm{~m}$ before the place of measurement). Measurements and sampling were carried out between 10:00 and 12:00 h local time to avoid the increase in wind speed that typically occurs in summer after midday (local wind pattern). Waves were approximately 3 to $5 \mathrm{~cm}$ high, and wind speed on all occasions was $<4 \mathrm{~km} \mathrm{~h}^{-1}$. Water samples were collected at ca $10 \mathrm{~cm}$ depth with a $3 \mathrm{l}$ Schindler-Patalas sampler and kept in the dark at $4^{\circ} \mathrm{C}$ 
until processing. A research station at the shore of the Rocha River provided facilities for processing the samples on the day of collection.

Measurements of downwelling irradiance. Measurements were made on both sampling occasions under a clear sky with an International Light radiometer (IL-1400A) consisting of broadband SUL240/W (UV-B) and SUL033/W (UV-A) underwater sensors ( $2 \pi$ cosine-corrected quartz diffuser). As discussed by Kirk et al. (1994), the effective bandwidth in sunlight of the UV-B sensor is not clearly specified by the manufacturer, but is assumed to be $20 \mathrm{~nm}$ with a peak response at $311 \mathrm{~nm}$ (air). The UV-A sensor measures from 315 to $390 \mathrm{~nm}$ with a peak response at $365 \mathrm{~nm}$. Simultaneously, PAR profiles were made with a LI-192SA $2 \pi$ quantum sensor connected to a LI-250 (Li-Cor) datalogger. The 3 sensors were mounted on an acrylic base that was submersed away from the boat by means of a calibrated rod that also allowed precise depth measurements $( \pm 1 \mathrm{~cm})$. Irradiance values were recorded as the average of $30 \mathrm{~s}$ registration at each depth. The main advantage of the IL sensors is that they are small and therefore suitable for measurement of UV penetration in shallow water columns. On the other hand, the UV-B sensor tends to shift to longer wavelengths with increasing depth (Kirk et al. 1994). In February 1998, parallel downward profiles (3 at each station) were measured with a PUV-500B underwater filter radiometer (Biospherical Instruments) at the nominal wavelengths of 305, 320, 340 and $380 \mathrm{~nm}$, as well as in the PAR range. Our PUV model is $36 \mathrm{~cm}$ long and has a $50 \mathrm{~m}$ pressure transducer to increase depth resolution in shallow waters. All sensors were placed in the water for several minutes before the readings, and the first profiles were made with the sensors covered by neoprene or rubber caps. Diffuse attenuation coefficients $\left(K_{\mathrm{d}}\right)$ were calculated assuming an exponential decrease of irradiance according to Kirk (1994a):

$$
E_{\mathrm{d}}(Z)=E_{\mathrm{d}}\left(0^{-}\right) \mathrm{e}^{-K_{\mathrm{d}} Z}
$$

where $E_{\mathrm{d}}(Z)$ is the value of irradiance at depth $Z(\mathrm{~m})$, $E_{\mathrm{d}}\left(0^{-}\right)$is the value of irradiance just below the surface (the first $5 \mathrm{~cm}$ were removed for the calculation), and $K_{\mathrm{d}}$ is the diffuse attenuation coefficient for the depth interval $0^{-}$to $Z(\mathrm{~m})$. Between 25 and 35 points for the IL-1400A and the LI-250, and between 50 and 80 points for the PUV-500B were used for the calculation of $K_{\mathrm{d}}$. The determination coefficients $\left(\mathrm{r}^{2}\right)$ of the $K_{\mathrm{d}}$ calculations were $>0.96$ and the standard errors $<0.03$. The depth corresponding to $10 \%$ of the irradiance at the surface $\left(Z_{10 \%}\right)$ was calculated as $2.3 / K_{\mathrm{d}}$. The portion of the water column corresponding to the $Z_{10} \%$ was estimated as the ratio $Z_{10 \%}$ to the water column depth $\left(Z_{10 \%} / Z_{\max }\right)$.
Dissolved organic carbon. DOC measurements were used as an index of the concentration of the CDOM. For this, $150 \mathrm{ml}$ of water were filtered through Whatman GF/F glass-fiber filters (pre-combusted for $1 \mathrm{~h}$ at $450^{\circ} \mathrm{C}$ ) within $3 \mathrm{~h}$ of sampling. Filtration was done by hand, with acid-washed glass syringes and stainlesssteel filter holders, directly over the bottle to avoid contamination. Whatman GF/F filters were used instead of $0.2 \mu \mathrm{m}$ filters because muffling of GF/F reduces significantly contamination of the sample by the filters (Yoro et al. 1999). The first $50 \mathrm{ml}$ were discarded and the final volume was collected in $100 \mathrm{ml}$ glass bottles with glass stoppers (Schott) and no head space. The bottles had previously been cleaned with acid, thoroughly rinsed with Milli-Q water, and pre-combusted for at least $2 \mathrm{~h}$ at $475^{\circ} \mathrm{C}$. The filtered samples were acidified to $\mathrm{pH} 2$ with $1 \mathrm{~N} \mathrm{HCl}$ (pure grade) and stored at $4^{\circ} \mathrm{C}$ in the dark until analysis (within $3 \mathrm{wk}$ ). The DOC concentration was measured with a high-temperature catalytic oxidation method in a Shimadzu TOC analyzer (Model 5000) equipped with a Shimadzu platinizedquartz catalyst for high-sensitivity analysis (Benner \& Strom 1993). Three to 5 injections were analyzed for each sample and blanks (Milli-Q water). Blank values (0.03 to $0.05 \mathrm{mg} \mathrm{l}^{-1}$ ) were subtracted from the average DOC value of the samples. Standardization of the instrument was done with potassium hydrogen phthalate (4-point calibration curve). The TOC analyzer used participates regularly in intercomparisons organized by the Norwegian Institute for Water Research (NIVA) for 57 laboratories.

Absorption and fluorescence of chromophoric dissolved organic matter. Absorption $\left(a_{\mathrm{d}}\right)$ of the dissolved fraction (filtration as for DOC) was measured in a double-beam spectrophotometer Hitachi U-2000 (with PC output) between 250 and $750 \mathrm{~nm}$ using acidcleaned $10 \mathrm{~cm}$ fused silica cuvettes (Suprasil I) prerinsed gently with Milli-Q water and twice with the filtered sample. Milli-Q water of low DOC concentration was used as a reference. Absorption coefficients were calculated as: $a_{\mathrm{d}}=2.303 D / 1$, where $D$ is absorbance and $l$ is the path length of the cuvette in meters (Kirk 1994a). All absorbance spectra were corrected for scattering by subtracting the absorbance value at $700 \mathrm{~nm}$. Spectral slopes of absorption coefficients between 280 and $400 \mathrm{~nm}$ were calculated using the equation of Bricaud et al. (1981): $a_{\mathrm{d}}(\lambda)=a_{\mathrm{d}}(r)$ $\exp \left[S_{a}(r-\lambda)\right]$, and where $a_{\mathrm{d}}(\lambda)$ and $a_{\mathrm{d}}(r)$ are the absorption coefficients at wavelength $\lambda$ and reference wavelength $r_{i} S_{a}$ is the slope of the equation. In addition, the intercept on the $y$-axis $\left(I_{a}\right)$ and the value of $a_{\mathrm{d}}$ centered in the middle of the UV range, i.e., $340 \mathrm{~nm}$, were calculated.

Samples for fluorescence $F_{\mathrm{d}}$ measurements were filtered as for DOC and the filtrates collected in $30 \mathrm{ml}$ 
vials (Wheaton, acid-washed, gently rinsed with Milli-Q, and pre-combusted as above) with teflonfaced silicon septa in open-top closures. Spectra of fluorescence emission were measured at room temperature in an Hitachi F-4500 spectrofluorometer (excitation at $355 \mathrm{~nm}$, slit width of $5 \mathrm{~nm}$ ) using a $1 \mathrm{~cm}$ cuvette (Suprasil I), pre-rinsed gently with Milli-Q water and with the filtered sample. The fluorescence response at $450 \mathrm{~nm}$ was normalized to the Raman signal area (integral) to give $F_{\mathrm{d}}$ in Raman units $\left(\mathrm{nm}^{-1}\right)$.

Chl $a$, organic and inorganic suspended solids. For chl a measurements, 500 to $1000 \mathrm{ml}$ of water were filtered through Whatman GF/F filters on the same sampling day. The filters were stored at $-20^{\circ} \mathrm{C}$ and processed within 2 wk. Pigments were extracted with $90 \%$ acetone overnight in the dark at $4^{\circ} \mathrm{C}$. Filters were briefly sonicated with a tip sonicator (1 $\mathrm{min})$, and the extracts were cleared using $0.1 \mu \mathrm{m}$ pore-size Whatman Anodisc filters. The extracts were scanned between 400 and $750 \mathrm{~nm}$ against an acetone reference in the same spectrophotometer as above, using $5 \mathrm{~cm}$ glass cuvettes. The equations of Jeffrey \& Humphrey (1975) were used to calculate the concentration of pigments.

Suspended solids were determined gravimetrically. For this, 500 to $1500 \mathrm{ml}$ were filtered through Whatman GF/C filters (pre-washed with deionized water and pre-combusted as for GF/F filters). After filtration was complete, the filters were washed 3 times with $20 \mathrm{ml}$ deionized water and then dried for $24 \mathrm{~h}$ at $105^{\circ} \mathrm{C}$. The residue was weighed in an analytical balance (precision $\pm 0.1 \mathrm{mg}$ ) to calculate the total concentration of suspended solids. The organic content of the suspended solids was estimated as the loss weight after ignition at $450^{\circ} \mathrm{C}$ for $2 \mathrm{~h}$ (APHA 1995).

Conductivity, water temperature and meteorological data. Profiles of conductivity (value given is for $25^{\circ} \mathrm{C}$ ) and temperature were done in situ with an ES-12 Horiba probe. Air temperature, rainfall, and wind data were provided by the National Meteorological Service for the nearest station, located at $3 \mathrm{~km}$ distance NE from the lagoon.

Statistical analysis. Statistical relationships among the variables were tested with the non-parametric Spearman's rank-correlation $\left(r_{S}\right)$. In order to limit the overall experimentwise error rate, each comparison was tested using a corrected significance level according to the Bonferroni method. Significant differences between variables were evaluated by means of MannWhitney (M-W) or Wilcoxon (W) signed-ranks tests. Stepwise multiple linear regressions were performed to determine the dependence of the UV and PAR attenuation coefficients on different attenuating factors. All statistical analyses were performed with SigmaStat (SPSS Inc.).

\section{RESULTS}

\section{Meteorological and hydrological conditions}

We selected 2 sampling occasions to represent 2 distinct hydrological conditions: March 1997 (marine intrusion) and February 1998 (freshwater dominance), hereafter refered to as open and closed situations, respectively. The mean water temperature in the lagoon was similar for the open and closed situations $\left(22.8 \pm 1.9\right.$ and $22.4 \pm 1.5^{\circ} \mathrm{C}$, respectively) and resembled that of the air $\left(21.0 \pm 5.3\right.$ and $20.7 \pm 5.4^{\circ} \mathrm{C}$, respectively; Fig. 2). Weak northern winds prevailed before and during the measurements (average between 10 and $12 \mathrm{~h}$ for both samplings $=2.3 \pm 2.2 \mathrm{~km} \mathrm{~h}^{-1}$; Fig. 2)

The cumulative rainfall during the 2 mo before each sampling was similar (148.6 and $155.5 \mathrm{~mm}$ for 1997 and 1998, respectively, Fig. 2). However, the week before the first sampling, the cumulative rainfall was ca $30 \mathrm{~mm}$, while the corresponding value for the second sampling was only $2 \mathrm{~mm}$ (Fig. 2). Furthermore, the first sampling coincided with a marine intrusion that began in January, while the second sampling occurred when the lagoon had not been connected with the ocean for ca 5 mo (Fig. 2). During the closed situation, the water depth increased at all stations (1.2- to 2.8-fold), although the increase was higher at the Stns D to E (Table 1). In the vicinity of Stn $\mathrm{H}$, a mass bloom of the submerged macrophyte Potamogeton sp. was observed during the closed situation.

Conductivity values along the main axis of the lagoon (Stns B to $\mathrm{H}$ ) were higher during the open situation (Fig. 3A) due to the marine intrusion, which resulted in an area of high conductivity ( $>45 \mathrm{mS} \mathrm{cm}^{-1}$ ) close to the marine entrance and an intermediate zone (ca $30 \mathrm{mS} \mathrm{cm}^{-1}$ ) in the central zone (Stns D to $\mathrm{F}$, Fig. 3A). Even in the northern area close to the main tributary (Rocha River, Stn $\mathrm{H}$ ), the conductivity was high (ca $16 \mathrm{mS} \mathrm{cm}^{-1}$ ). During the closed period, the conductivity in the whole system decreased, and the values in the south and central zones were more homogeneous (14.8 to $20.8 \mathrm{mS} \mathrm{cm}^{-1}$, Fig. 3A). Under both hydrological conditions, the tributary (Stn I) displayed low conductivity $\left(0.2 \mathrm{mS} \mathrm{cm}^{-1}\right)$. On both sampling occasions, no vertical gradients of conductivity or temperature were observed in the water column.

\section{Penetration of UV and PAR into the water column}

During the whole study, the $K_{\mathrm{d}}$ values for UV-B and UV-A ranged from 7 to $64 \mathrm{~m}^{-1}$ and from 2 and $16 \mathrm{~m}^{-1}$, respectively (see Table 1 for $Z_{10 \%}$ values). Remarkable differences in the penetration of UV were observed for each hydrological condition, especially in the southern 


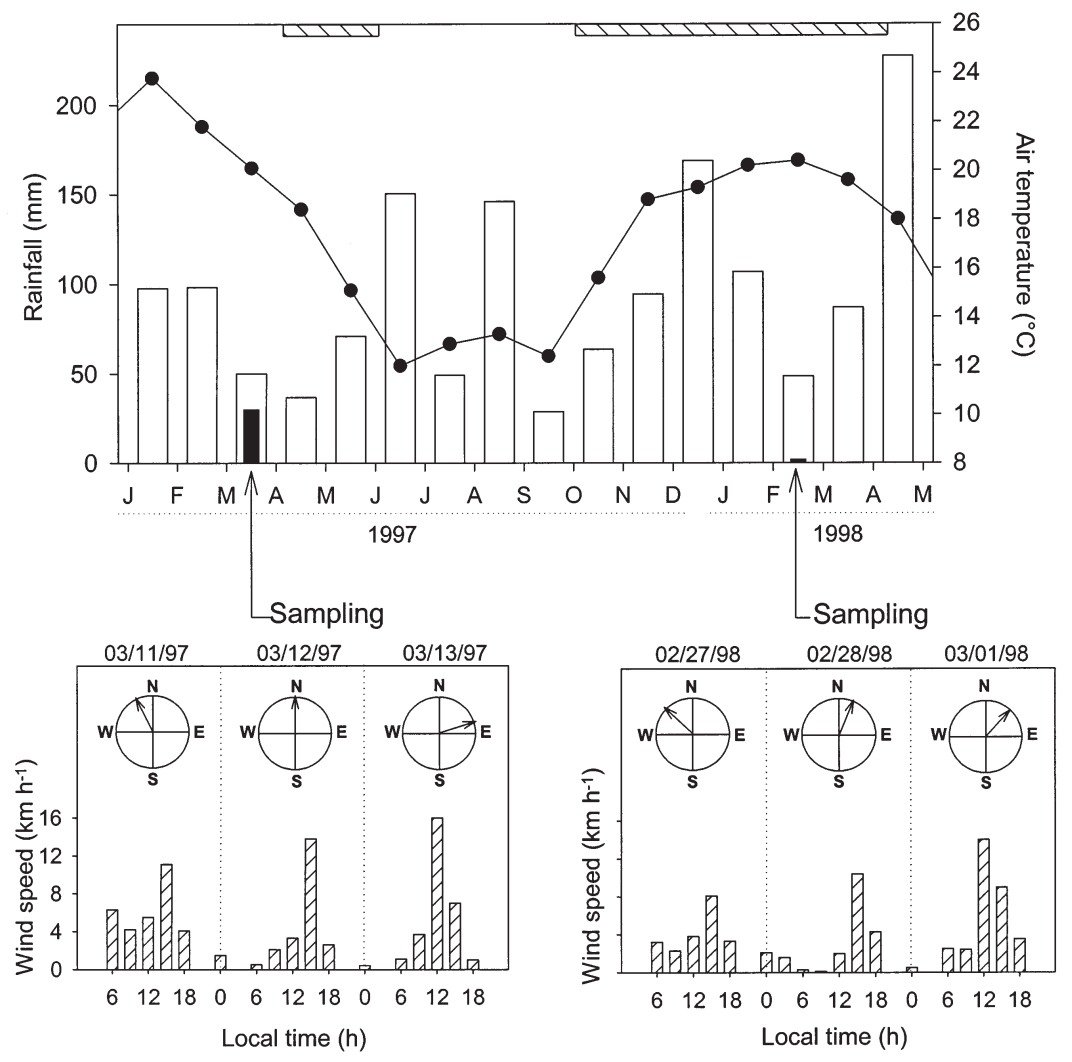

Fig. 2. Meteorological data for study period. Upper graph: average air temperature (๑) and monthly-accumulated rainfall (bars) between January 1997 and May 1998; Horizontal striped bars = periods when sand bar was closed; black vertical bars = cumulative rainfall of week before each sampling. Bottom graphs: wind speed (bars) and direction (wind roses) during days of samplings; wind direction is average value registered during field work (10:00 to 12:00 h). Dates are given as mo/d/yr

Table 1. Water depth $\left(Z_{\max }\right), Z_{10 \%}$ (depth of $10 \%$ of surface irradiance) and $Z_{10 \%} / Z_{\max }$ (percentage of water column covered by $Z_{10 \%}$ ) for UV-B, UV-A and PAR along main axis of Laguna de Rocha and main tributary in March 1997 (Open period) and February 1998 (Closed period). -: no data; ${ }^{*} 100 \%$ of surface radiation reached the sediment

\begin{tabular}{|c|c|c|c|c|c|c|c|}
\hline Stn & $\begin{array}{c}Z_{\max } \\
(\mathrm{m})\end{array}$ & $\begin{array}{l}Z_{10 \% \text { UV-B }} \\
(\mathrm{m})\end{array}$ & $\begin{array}{l}Z_{10 \% \text { UV-A }} \\
(\mathrm{m})\end{array}$ & $\begin{array}{c}Z_{10 \% \text { PAR }} \\
(\mathrm{m})\end{array}$ & $\begin{array}{c}Z_{10 \% \text { UV-B }} / Z_{\max } \\
(\%)\end{array}$ & $\begin{array}{c}Z_{10 \% \text { UV-A }} / Z_{\max } \\
(\%)\end{array}$ & $\begin{array}{c}Z_{10 \% \mathrm{PAR}} / Z_{\max } \\
(\%)\end{array}$ \\
\hline \multicolumn{8}{|c|}{ Open period } \\
\hline A & - & - & - & - & - & - & - \\
\hline B & 0.5 & 0.31 & 1.10 & 1.64 & 65.6 & $100.0^{*}$ & $100.0^{*}$ \\
\hline C & 0.5 & 0.07 & 0.24 & 0.88 & 13.4 & 48.0 & $100.0^{*}$ \\
\hline $\mathrm{D}$ & 0.5 & 0.08 & 0.30 & 0.82 & 14.9 & 56.4 & $100.0^{*}$ \\
\hline $\mathrm{E}$ & 0.5 & 0.05 & 0.32 & 1.10 & 9.9 & 63.9 & $100.0^{*}$ \\
\hline $\mathrm{F}$ & 0.6 & 0.05 & 0.18 & 0.96 & 8.6 & 30.2 & $100.0^{*}$ \\
\hline $\mathrm{G}$ & 0.4 & 0.05 & 0.22 & 0.79 & 10.8 & 50.5 & $100.0^{*}$ \\
\hline $\mathrm{H}$ & 0.4 & 0.04 & 0.17 & 0.45 & 10.3 & 41.4 & $100.0^{*}$ \\
\hline I & 2.1 & 0.04 & 0.15 & 0.43 & 1.7 & 7.1 & 20.3 \\
\hline \multicolumn{8}{|c|}{ Closed period } \\
\hline A & - & - & - & - & - & - & - \\
\hline B & 0.7 & 0.09 & 0.33 & 1.35 & 13.5 & 45.6 & $100.0^{*}$ \\
\hline $\mathrm{C}$ & 0.7 & 0.09 & 0.35 & 1.21 & 14.0 & 53.7 & $100.0^{*}$ \\
\hline $\mathrm{D}$ & 1.3 & 0.08 & 0.28 & 1.44 & 6.3 & 21.4 & $100.0^{*}$ \\
\hline $\mathrm{E}$ & 1.4 & 0.08 & 0.25 & 1.44 & 5.8 & 18.2 & $100.0^{*}$ \\
\hline $\mathrm{F}$ & 1.0 & 0.09 & 0.24 & 1.00 & 9.4 & 23.7 & $100.0^{*}$ \\
\hline $\mathrm{G}$ & 0.7 & 0.09 & 0.29 & 1.35 & 13.4 & 44.8 & $100.0^{*}$ \\
\hline $\mathrm{H}$ & 0.8 & 0.07 & 0.18 & 0.72 & 8.8 & 22.3 & 89.8 \\
\hline I & 2.5 & 0.12 & 0.28 & 1.35 & 4.9 & 11.3 & 54.1 \\
\hline
\end{tabular}



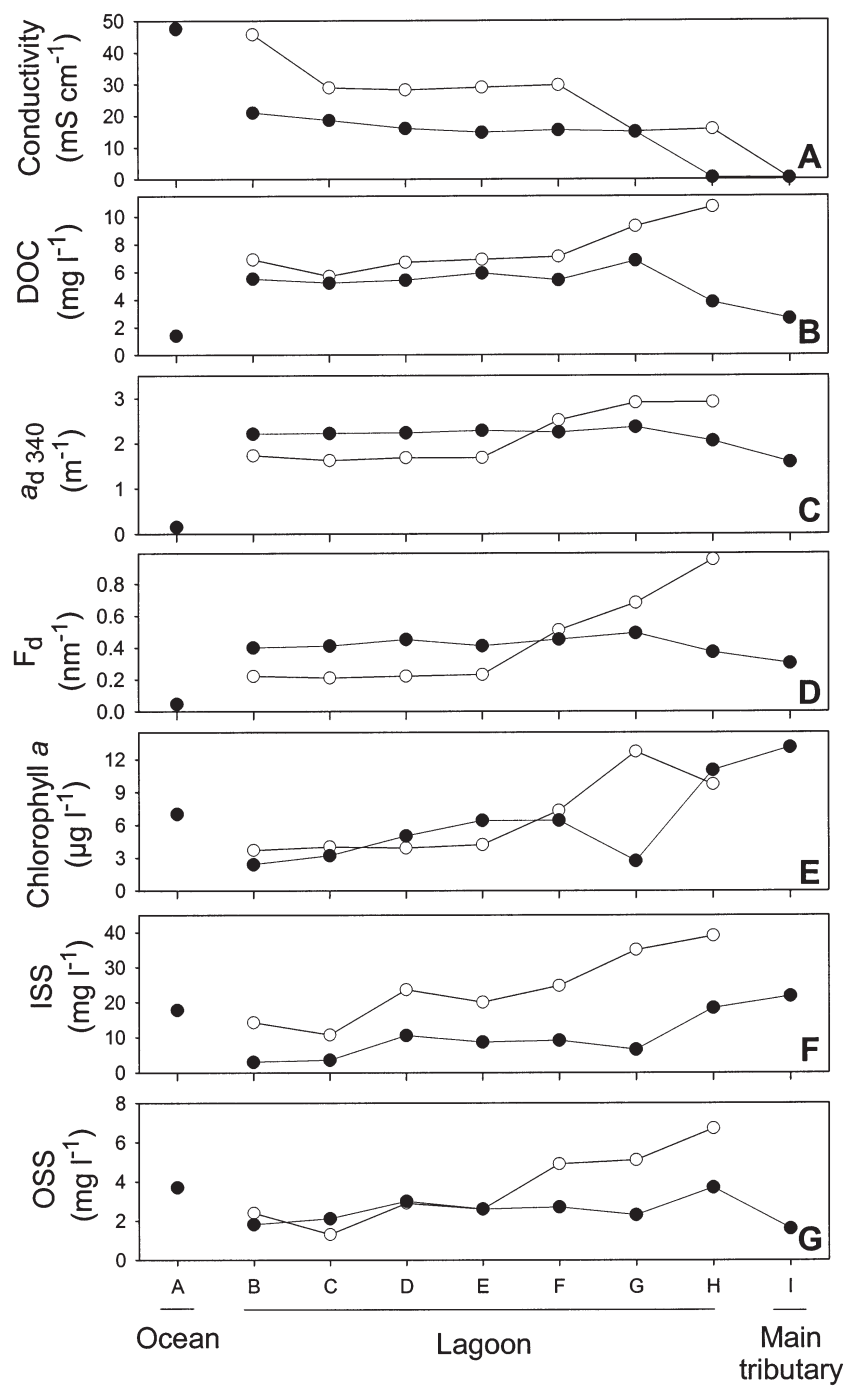

SAMPLING STATIONS

Fig. 3. Spatial gradients along main axis of Laguna de Rocha and main tributary in March 1997 (open situation, O) and February 1998 (closed situation, •) of conductivity (A), dissolved organic carbon (DOC, B), absorption at $340 \mathrm{~nm}\left(a_{\mathrm{d} 340}, \mathrm{C}\right)$, CDOM fluorescence in Raman units $\left(F_{\mathrm{d}}, \mathrm{D}\right)$, chlorophyll a $(\mathrm{E})$, inorganic suspended solids (ISS, F), and organic suspended solids (OSS, G). In (A), values of conductivity for Stns G and I were the same in both samplings. See Fig. 1 for sampling stations

area of the lagoon. At Stn B, the $K_{\mathrm{d}}$ values for UV-B and UV-A were $>3$ times lower during the open than during the closed situation (Fig. 4). The corresponding $Z_{10 \%}$ UV-B and $Z_{10 \%}$ UV-A during the open situation were 0.3 and $1.1 \mathrm{~m}$, respectively, while the values for the same wavebands were reduced during the closed situation to 0.1 and $0.3 \mathrm{~m}$, respectively (Table 1, Fig. 4). The stations corresponding to the central area of the lagoon (D to F) showed similar $Z_{10 \%}$ under both conditions (range $=0.05$ to $0.09 \mathrm{~m}$ for UV-B and 0.18 to
$0.32 \mathrm{~m}$ for UV-A; Table 1 ). Average $Z_{10} \%$ for UV-B at the stations close to the freshwater zone and on the main tributary (G, H and I) was 0.04 and $0.09 \mathrm{~m}$ under the open and closed situations, respectively.

The $Z_{10 \%} / Z_{\max }$ ratio for UV-B and UV-A was highest under the marine influence at the southernmost station (B), reaching 66 and $100 \%$ of the water column, respectively (Table 1). During the closed period at the same station, the values decreased to 14 and $46 \%$, for UV-B and UV-A, respectively. For the other stations in the lagoon there was no significant difference between the open and closed situations in the $Z_{10 \%} / Z_{\max }$ ratio ( $p>0.05 \mathrm{~W}$ test). At the main tributary (Stn I), the penetration of UV-B and UV-A was always lower than 5 and $11 \%$ of the water column, respectively.

PAR attenuation coefficients (1.4 to $\left.5.4 \mathrm{~m}^{-1}\right)$ exhibited a spatial and temporal variation pattern similar to that observed for the UV wavebands, with the lowest values found close to the marine area during the open situation. Except for Stns $\mathrm{H}$ and I, all $Z_{10 \%} / Z_{\max }$ ratios for PAR were $100 \%$ (Table 1).

During the second sampling, simultaneous UV profiles were done with the IL-1400A sensors and the PUV-500B radiometer (the channels with the nominal wavelengths of $320 \mathrm{~nm}$ and $380 \mathrm{~nm}$ were compared). The $K_{\mathrm{d}}$ calculated were all very highly significantly correlated $\left(r_{s}>0.975, \mathrm{n}=13, \mathrm{p}<0.001\right)$; however, the $K_{\mathrm{d}}$ values estimated from the PUV were significantly

\section{Irradiance (\% of the surface)}

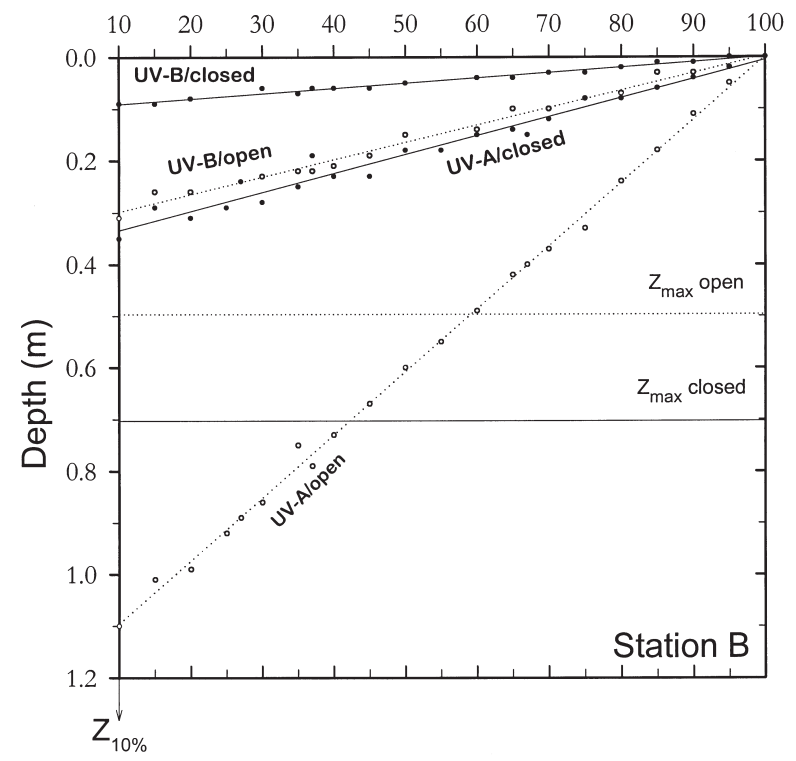

Fig. 4. Depth profiles of UV irradiance (percentage of surface value) at Stn B of Laguna de Rocha in March 1997 (dotted lines) and February 1998 (continuous lines). Maximum depth $\left(Z_{\max }\right)$ at each sampling is also shown. All $\mathrm{r}^{2}$ were $>0.96$ and standard errors $<0.02$ 
lower ( $p<0.01, \mathrm{~W}$ test) than those estimated with the IL. For example, the $K_{\mathrm{d}}$ values estimated for the PUV were on average $10.3 \pm 3.4 \%(320 \mathrm{~nm})$ and $14.2 \pm 3.5 \%$ $(380 \mathrm{~nm})$ lower than those estimated for the IL sensors.

\section{Characteristics of CDOM}

The average DOC concentration for the stations on the main axis of the lagoon was $6.3 \mathrm{mg} \mathrm{l}^{-1}$ in March 1997 (coefficient of variation, $\mathrm{CV}=36 \%$ ) and $5.4 \mathrm{mg} \mathrm{l}^{-1}$ in February $1998(\mathrm{CV}=16 \%)$. These sets of values were not significantly different ( $p>0.05, \mathrm{M}-\mathrm{W}$ test), although important changes in DOC concentration were found between sampling situations at both ends of the system (Fig. 3B). At the southernmost area (Stn B), the DOC increased from 1.8 (open) to $5.5 \mathrm{mg} \mathrm{l}^{-1}$ (closed), while at the stations directly influenced by the freshwater tributaries, the average DOC concentration decreased from $8.2 \pm 1.6 \mathrm{mg} \mathrm{l}^{-1}$ (open) to $5.3 \pm$ $2.1 \mathrm{mg} \mathrm{l}^{-1}$ (closed). On both sampling occasions, the DOC content was highly significantly correlated with the absorption at $254 \mathrm{~nm}\left(r_{s}=0.948\right.$ and 0.980 , for the open and closed sampling occasions, respectively; $\mathrm{p}<0.001$ ).

The values of $a_{\mathrm{d} 340}$ in the lagoon and the main tributary ranged from 0.29 to $2.91 \mathrm{~m}^{-1}$ in the open situation and from 1.58 to $2.36 \mathrm{~m}^{-1}$ in the closed situation (Fig. $3 C$ ). At Stn B, the $a_{\mathrm{d} 340}$ value increased by 1 order of magnitude, associated with a 3-fold increase in the DOC content. Values of $S_{a}$ (i.e., the spectral slope) for all measurements ranged from 0.0153 to $0.0198 \mathrm{~nm}^{-1}$ (Table 2), with mean values of $0.0178 \pm 0.0019$ and $0.0179 \pm 0.0012 \mathrm{~nm}^{-1}$ for the open and closed situations, respectively ( $p>0.05, \mathrm{M}-\mathrm{W}$ test). The intercept on the $y$-axis, $I_{a}$ varied between 5.48 and $8.73 \mathrm{~m}^{-1}$ (Table 2), with a mean value for the open and closed situations of $7.95 \pm 1.01$ and $8.18 \pm 0.90 \mathrm{~m}^{-1}$, respectively. The stations located at both extremes of the lagoon $(\mathrm{B}, \mathrm{G}, \mathrm{H})$ exhibited the highest differences in $I_{a}$ and $S_{a}$ between samplings (Table 2). Stns C, D, E and F presented minor differences between both hydrological situations. In the freshwater zone ( $\mathrm{H}$ and I), $a_{\mathrm{d} 340}$ (Fig. 3C) and $I_{a}$ values decreased, while $S_{a}$ increased from the open to the closed situation. Although during the open situation most parameters (ISS, OSS, chl $a_{1} F_{\mathrm{d}}$, DOC) were negatively correlated with conductivity, $a_{\mathrm{d} 340}$ was the only parameter significantly correlated (Table 3 ). On both samplings situations, $a_{\mathrm{d} 340}$ was very highly significant correlated ( $\mathrm{p}<0.001$ ) with the DOC concentration $\left(r_{s}=0.982\right.$ and 0.923 , for the open and closed situations, respectively). However, values of $I_{a}$ and $S_{a}$ were not significantly correlated with this parameter $(p>0.05)$. When $a_{\mathrm{d} 340}$ was normalized to the DOC concentration $\left(a_{\mathrm{d}}{ }^{*}{ }^{*}{ }^{3}\right)$, values during the closed situation were significantly higher $(\mathrm{p}=0.016, \mathrm{~W}$ test $)$ than during the open situation (Table 2).

Regarding the absorption spectra of the CDOM in the UV range, 3 groups of stations were differentiated during the open situation (Fig. 5A) corresponding with a south-north gradient in DOC content. In contrast, during the closed situation, the plots were more similar (Fig. 5B), with the exception of the spectral absorption at Stns $\mathrm{H}$ and I that was slightly lower than in the rest of the lagoon.

The $F_{\mathrm{d}}$ values were highly significantly correlated (Table 3, Fig. 3D) with DOC concentration and with absorption at $340 \mathrm{~nm}$ (wavelength close to that used for excitation: $355 \mathrm{~nm}$ ). As expected, the $F_{\mathrm{d}}$ values for the stations at the southern and central areas of the lagoon (Stns B to F) were significantly lower $(\mathrm{p}<0.01 \mathrm{M}-\mathrm{W}$ test) during the open situation (Fig. 3D). The $F_{\mathrm{d}}$ values during the open sampling increased towards the tributaries, while during the closed situation the values were similar along the whole system.

\section{Attenuating factors in the particulate fraction}

The average concentration of chl a for all stations was 6.1 and $6.3 \mathrm{\mu g} \mathrm{l}^{-1}$ during the open and closed periods, respectively, and was not significantly different between sampling periods ( $p>0.5, \mathrm{M}-\mathrm{W}$ test, Fig. 3E). In contrast to chl $a$, the concentrations of inorganic suspended solids (ISS) decreased significantly $(p<0.05$ $\mathrm{M}-\mathrm{W}$ test) during the closed period (Fig. 3F, mean for open and closed situations: 22.4 and $10.2 \mathrm{mg} \mathrm{l}^{-1}$, respectively). The mean concentration of organic suspended solids (OSS) decreased slightly from 3.3 (open)

Table 2. Natural logarithm of absorption at $340 \mathrm{~nm}$ normalized to DOC concentration $\left(a_{\mathrm{d}}{ }^{*}{ }_{340}\right)$ and spectral parameters describing relationship between $a_{\mathrm{d}}$ and wavelength (280 to $400 \mathrm{~nm}$ ) for 9 stations at Laguna de Rocha and Rocha River in March 1997 (Open) and February 1998 (Closed). $I_{a}$ : intercept on $y$-axis; $S_{a}$ : spectral slope; -: no data. Regressions were performed on ln-transformed absorption values

\begin{tabular}{|lcccccc|}
\hline Stn & $\begin{array}{c}a_{\mathrm{d}}{ }^{*}{ }^{340} \\
\left(\mathrm{~m}^{-1}\right)\end{array}$ & \multicolumn{2}{c}{$\begin{array}{c}I_{a} \\
\left(\mathrm{~m}^{-1}\right)\end{array}$} & \multicolumn{2}{c|}{$\begin{array}{c}S_{a} \\
\left(\mu \mathrm{m}^{-1}\right)\end{array}$} \\
& Open Closed & \multicolumn{2}{c}{ Open Closed } & \multicolumn{2}{c}{ Open Closed } \\
A & - & 0.107 & - & 5.78 & - & 16.6 \\
B & 0.161 & 0.402 & 5.48 & 8.54 & 15.3 & 18.6 \\
C & 0.251 & 0.427 & 8.27 & 8.59 & 19.2 & 18.7 \\
D & 0.284 & 0.413 & 8.28 & 8.72 & 19.6 & 19.1 \\
E & 0.251 & 0.386 & 8.39 & 8.73 & 19.8 & 19.0 \\
F & 0.244 & 0.415 & 8.26 & 8.66 & 19.4 & 18.9 \\
G & 0.354 & 0.348 & 8.11 & 8.67 & 16.5 & 18.6 \\
H & 0.311 & 0.539 & 8.28 & 7.84 & 15.8 & 17.0 \\
I & 0.271 & 0.608 & 8.53 & 7.54 & 16.5 & 17.5 \\
\hline
\end{tabular}



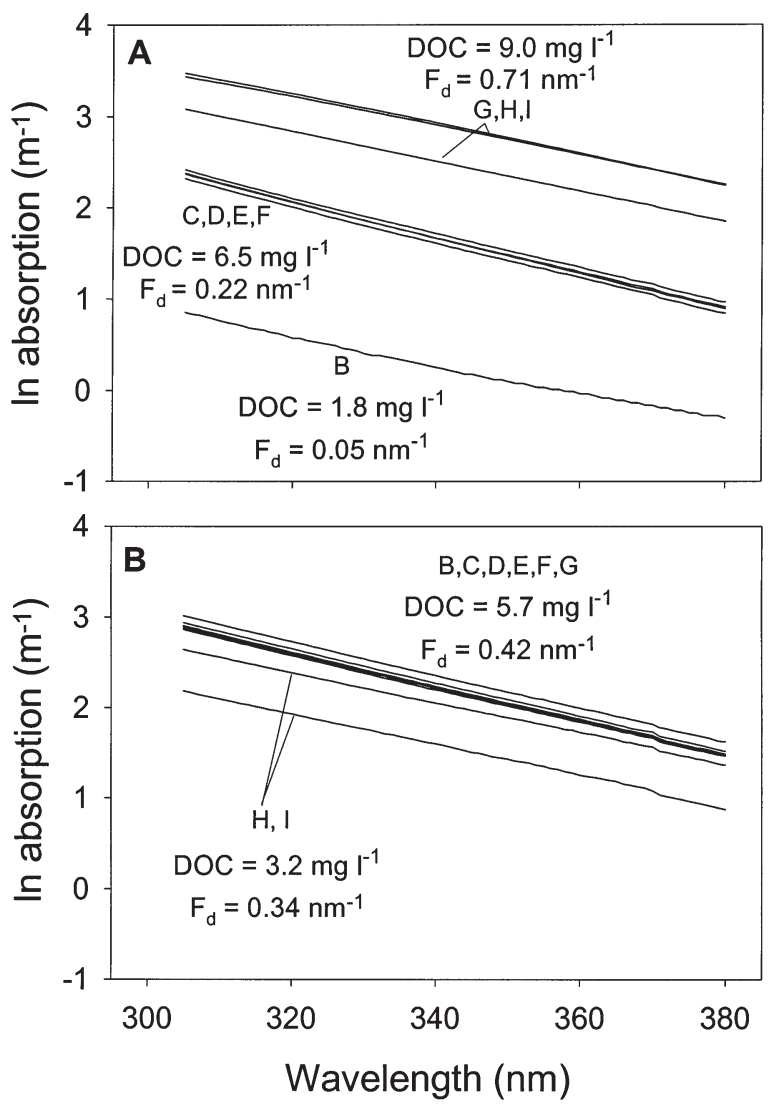

Fig. 5. Spectral absorption of CDOM for 8 stations located along main axis of Laguna de Rocha and its main tributary. (A) March 1997 (lagoon connected to ocean); (B) February 1998 (lagoon isolated from ocean). Mean values of dissolved organic carbon (DOC) and CDOM fluorescence $\left(F_{\mathrm{d}}\right)$ are indicated for each group of stations. $\mathrm{r}^{2}$ for all regressions ranged from 0.992 to 0.999 . See Fig. 1 for sampling stations

to $2.5 \mathrm{mg} \mathrm{l}^{-1}$ (closed, Fig. 3G), although differences were more pronounced at Stns G to I. During the open situation, both ISS and OSS increased from the marine to the freshwater area (3- to 6-fold, respectively), while during the closed situation no clear spatial pattern was observed in the lagoon, although values of ISS were higher at Stns $\mathrm{H}$ and I (Fig. 3F,G). The OSS and chl a values were significantly correlated (Table 3).

\section{Relationship between $K_{\mathrm{d}}$ and attenuating factors}

During the open situation, the $K_{\mathrm{d}}$ values for both UV$\mathrm{B}$ and UV-A were significantly correlated with DOC (UV-B, $r_{s}=0.929, \mathrm{p}<0.01 ; \mathrm{UV}-\mathrm{A}, r_{s}=0.952, \mathrm{p}<0.001$ ), while for PAR the correlation with this variable was lower $\left(r_{s}=0.833, \mathrm{p}<0.05\right)$ (Table 3$)$. The $K_{\mathrm{d}}$ for UV-B radiation was significantly correlated $(\mathrm{p}<0.001)$ with $F_{\mathrm{d}}$, ISS and OSS and chl a $(\mathrm{p}<0.05)$ (Table 3$)$. In con- trast, during the closed situation, $K_{\mathrm{d}}$ for UV-B and UVA was not significantly correlated ( $p>0.05$ ) with any of the above-mentioned variables except OSS $(\mathrm{p}<0.05$; data not shown).

To test the contribution of different factors to the variability of $K_{\mathrm{d}}$ during the open situation, we used a stepwise multiple linear regression analysis (Table 4). The variability of $K_{\mathrm{d}}$ in UV-B was best explained by the inclusion of DOC and OSS (adjusted $\mathrm{r}^{2}=0.902$ ), while the $K_{\mathrm{d}}$ values for both UV-A and PAR were best predicted by the concentration of DOC and chl a (adjusted $\mathrm{r}^{2}=0.836$ and 0.886 , respectively). The inclusion of other variables did not improve the predictive power of the regressions.

\section{DISCUSSION}

\section{UV and PAR penetration into water column}

Although no direct comparison of $K_{\mathrm{d}}$ values can be made for UV measurements done with instruments of different optical characteristics, Kirk et al. (1994) showed that $K_{\mathrm{d}}$ values estimated with underwater IL sensors were in reasonable agreement with those obtained with other UV sensors. Our comparison of $K_{\mathrm{d}}$ values estimated with the IL and PUV radiometer also showed a good agreement. The $Z_{10} \%$ values found in our study fell within the range reported in the literature for marine and freshwater systems (Kirk 1994b) and coastal lagoons from the Baltic Sea (Piazena \& Häder 1994). However, the highest $K_{\mathrm{d}}$ values in our study were more typical of humic lakes or coastal areas influenced by large rivers such as in the Yellow Sea (Kirk 1994b, Xenopoulos \& Bird 1997). The UV penetration in Laguna de Rocha in the area influenced by the marine intrusion (approximately $1 / 5$ of the lagoon's area) was considerable, with the $Z_{10} \%$ UV-B and $Z_{10 \% \text { UV-A }}$ reaching 66 and $100 \%$ of the water column (0.3 and 1.1 $\mathrm{m}$, respectively), while in the central and northern area of the lagoon the penetration was much lower. This pattern, i.e., an increase in UV transparency from the freshwater zone towards the marine influence, is typical of other estuarine systems, such as, the Gulf of St. Lawrence (Kuhn et al. 1999).

According to the optical classification for natural waters of Jerlov (1970), our set of $K_{\mathrm{d}}$ for UV-B and UV-A exceeded values for the C9 type (top end of the classification for coastal waters), except for Stn B during the marine intrusion, which was close to the $\mathrm{C} 7$ type. Using the $K_{\mathrm{d}}$ values for UV-B and applying the extended classification to the 20 water types of Piazena \& Häder (1997), the central area of Laguna de Rocha fell between Types C13 and C15, while the northern area corresponded to Type C16 or higher. 
Table 3. Matrix of Spearman's correlations between optical variables and extinction coefficients for UV-B, UV-A, and PAR in March 1997 (lagoon connected to ocean, $\mathrm{n}=8$ ). Significant correlations after correcting significance level according to Bonferroni method are in bold. Significance level: ${ }^{* * *} \mathrm{p}<0.001{ }^{*}{ }^{* *} \mathrm{p}<0.01 ;{ }^{*} \mathrm{p}<0.05$

\begin{tabular}{|c|c|c|c|c|c|c|c|}
\hline Variable & $C_{T=25^{\circ} \mathrm{C}}$ & ISS & OSS & Chl a & $F_{\mathrm{d}}$ & DOC & $a_{\mathrm{d} 340}$ \\
\hline $\begin{array}{l}\text { Conductivity }\left(C_{T=25^{\circ} \mathrm{C}}\right) \\
\left(25^{\circ} \mathrm{C}, \mathrm{mS} \mathrm{cm}^{-1}\right)\end{array}$ & - & & & & & & \\
\hline $\begin{array}{l}\text { Inorganic suspended solids (ISS) } \\
\left(\mathrm{mg} \mathrm{l}^{-1}\right)\end{array}$ & -0.667 & - & & & & & \\
\hline $\begin{array}{l}\text { Organic suspended solids (OSS) } \\
\left(\mathrm{mg} \mathrm{l}^{-1}\right)\end{array}$ & -0.762 & $0.976^{* * *}$ & - & & & & \\
\hline $\begin{array}{l}\text { Chlorophyll a }(\mathrm{chl} a) \\
\left(\mu \mathrm{g} \mathrm{l}^{-1}\right)\end{array}$ & -0.760 & 0.786 & $0.857^{*}$ & - & & & \\
\hline $\begin{array}{l}\text { Fluorescence of CDOM }\left(F_{\mathrm{d}}\right) \\
\left(\mathrm{nm}^{-1}\right)\end{array}$ & -0.755 & $0.952^{* * *}$ & $0.976^{* * *}$ & $0.905^{* *}$ & - & & \\
\hline $\begin{array}{l}\text { Dissolved organic carbon (DOC) } \\
\left(\mathrm{mg} \mathrm{l}^{-1}\right)\end{array}$ & -0.758 & $0.905^{* *}$ & $0.923^{* *}$ & $0.850^{*}$ & $0.982^{* * *}$ & - & \\
\hline $\begin{array}{l}\text { Absorption at } 340 \mathrm{~nm}\left(a_{\mathrm{d} 340}\right) \\
\left(\mathrm{m}^{-1}\right)\end{array}$ & $-0.826^{*}$ & $0.898^{* *}$ & $0.922^{* *}$ & 0.790 & $0.946^{* *}$ & $0.982^{* * *}$ & - \\
\hline $\begin{array}{l}\left.\text { Attenuation coefficient for UV-B ( } K_{\mathrm{d} \text { UV-B }}\right) \\
\left(\mathrm{m}^{-1}\right)\end{array}$ & -0.762 & $0.976^{* * *}$ & $0.997^{* * *}$ & $0.857^{*}$ & $0.958^{* * *}$ & $0.929^{* *}$ & $0.922^{* *}$ \\
\hline $\begin{array}{l}\text { Attenuation coefficient for UV-A ( } K_{\mathrm{d} \text { UV-A })} \\
\left(\mathrm{m}^{-1}\right)\end{array}$ & -0.690 & -0.762 & $0.810^{*}$ & $0.881^{* *}$ & $0.934^{* *}$ & $0.952^{* * *}$ & $0.862^{*}$ \\
\hline $\begin{array}{l}\text { Attenuation coefficient for PAR }\left(K_{\mathrm{d}} \mathrm{PAR}\right) \\
\left(\mathrm{m}^{-1}\right)\end{array}$ & $-0.952^{* *}$ & 0.667 & 0.762 & $0.857^{*}$ & 0.814 & $0.833^{* *}$ & $0.850^{*}$ \\
\hline
\end{tabular}

Table 4. Summary of multiple regressions relating attenuation coefficients for UV-B, UV-A and PAR $\left(K_{\mathrm{d}} \mathrm{m}^{-1}\right)$ to diverse attenuation factors for all measurements performed at Laguna de Rocha $(n=8)$ in March 1997 (open situation). SE: standard error; SC: standardized coefficients

\begin{tabular}{|c|c|c|c|c|c|c|c|}
\hline $\begin{array}{l}\text { Dependent } \\
\text { variable }\end{array}$ & Independent variables & $\mathrm{SC}$ & Constant & $\begin{array}{l}\text { Adjusted } \\
\mathrm{r}^{2}\end{array}$ & $\begin{array}{l}\text { Model } \\
\mathrm{p}\end{array}$ & $\begin{array}{c}F \text {-ratio } \\
(2,14)\end{array}$ & $\begin{array}{c}\text { SE of } \\
\text { estimate }\end{array}$ \\
\hline \multirow[t]{2}{*}{$K_{\mathrm{d} \text { UV-B }}$} & DOC & 4.881 & & & & & \\
\hline & OSS & 2.358 & -0.0504 & 0.902 & 0.001 & 33.1 & 5.57 \\
\hline \multirow[t]{2}{*}{$K_{\mathrm{d} \text { UV-A }}$} & DOC & 1.490 & & & & & \\
\hline & Chl a & 0.064 & -0.730 & 0.836 & 0.005 & 18.9 & 1.74 \\
\hline \multirow[t]{2}{*}{$K_{\mathrm{d} \text { PAR }}$} & DOC & 0.240 & & & & & \\
\hline & Chl a & 0.235 & 0.005 & 0.886 & 0.002 & 28.2 & 0.48 \\
\hline
\end{tabular}

Information on the temporal and spatial dynamics of light attenuation and optical parameters in coastal lagoons is scarce. Our data show that the dynamics associated with the opening and closing of the sand bar exert a strong influence on UV attenuation. While on both sampling occasions the central area of the lagoon always presented high UV-B attenuation coefficients $\left(K_{\mathrm{d} \text { UV-B }}=29\right.$ to $\left.47 \mathrm{~m}^{-1}\right)$, the marine and freshwater ends of the system showed important changes in UV and PAR attenuation. For example, the lowest attenuation for UV-B was found under the marine influence in the southernmost zone $\left(K_{\mathrm{d} \text { UV-B }}=7 \mathrm{~m}^{-1}\right)$, while the highest attenuation was observed at the freshwater end $\left(K_{\mathrm{d} \text { UV-B }}=56\right.$ to $\left.64 \mathrm{~m}^{-1}\right)$ during the same sampling period. During the closed situation, the southern area had a much higher attenuation $\left(K_{\mathrm{d} \text { UV-B }}=\right.$ $24 \mathrm{~m}^{-1}$ ) than during the open period, with values more similar to those found in the northern zone $\left(K_{\mathrm{d} \text { UV-B }}=27\right.$ to $33 \mathrm{~m}^{-1}$ ). One exception, however, was observed during the closed situation at Stn $\mathrm{H}$. In this station, the higher UV and PAR penetration (lower DOC concentration, $a_{\mathrm{d}}$ and $F_{\mathrm{d}}$ values) compared to the open situation may be partially explained by the mass development of Potamogeton sp., which reduced the sediment resuspension in this zone. In addition, the cumulative rainfall the week before sampling during the closed situation was 15 times lower than during the open situation (Fig. 2), corresponding with the lower concentration of dissolved and particulate substances found in the main tributary (Fig. 3). 


\section{UV attenuating factors}

Underwater radiation in coastal lagoons is largely regulated by river discharge and the marine intrusions, which together with sediment resuspension are the main sources of dissolved and particulate substances in these systems (Arfi \& Bouvy 1995). The results of the multiple regression analysis (Table 4 ) show that during the open situation, the dissolved and particulate organic components played a major role in explaining the variability in UV-B attenuation. In the case of UVA and PAR, not only the DOC but also the phytoplankton explained most of the variability in attenuation. These results are in agreement with those obtained for other freshwater and estuarine environments where not only CDOM but also absorption and scattering by particles are dominant (Davies-Colley \& Vant 1987, Kirk 1994b, Piazena \& Häder 1997, Hodoki \& Watanabe 1998, Smith et al. 1999).

Dissolved and particulate organic substances in Laguna de Rocha are probably derived from different sources such as runoff, autochthonous algal and plant production, and by sediment resuspension (central and northern zone). The DOC content (1.8 to $10.7 \mathrm{mg} \mathrm{l}^{-1}$ ) varied from values commonly found in estuarine systems (Sharp et al. 1982, Fox 1983, Morales-Zamorano et al. 1991, Moran et al. 1999) to those typical of humic waters (Curtis \& Adams 1995). Both indicators of the optical characteristics of the CDOM, i.e., $a_{\mathrm{d}}$ and $F_{\mathrm{d}}$ were significantly correlated with DOC concentration and also showed a strong negative relationship with conductivity, suggesting that these parameters can be considered as conservative properties, i.e., mainly affected by the mixing ratio of marine and freshwater. Therefore, measurements of $a_{\mathrm{d}}$ and $F_{\mathrm{d}}$ seem to be suitable for studying the dynamics of surface circulation in Laguna de Rocha, particularly because they can be done in a rapid way and are sensitive (especially $F_{\mathrm{d}}$ ) (Nieke et al. 1997, Ferrari \& Dowell 1998).

The lower values of $a_{\mathrm{d}}{ }^{*} 340$ during the open situation (Table 2) indicate that the composition of absorbing chromophores in the CDOM changed. The CDOM introduced into the Laguna de Rocha from the adjacent coastal waters are expected to have a stronger autochthonous component than that CDOM found in the lagoon during the dominance of the river discharge (closed situation). Autochthonous CDOM (e.g., derived from algae) is known to have lower aromaticity and UV absorption than that of terrestrial origin (McKnight et al. 1994). In addition, the ratio of humic acid:fulvic acid of CDOM is known to change from riverine to marine systems and to affect the $a_{\mathrm{d}}{ }^{*}$ and spectral-slope parameters (Coble \& Brophy 1994).

Our $S_{a}$ values ( 0.015 to $0.020 \mathrm{~nm}^{-1}$ ) were similar to the range reported for other systems $(0.010$ to
$0.020 \mathrm{~nm}^{-1}$ ) (Davies-Colley \& Vant 1987, Morris et al. 1995, Nieke et al. 1997, Ferrari \& Dowell 1998); however, direct comparison is difficult because $S_{a}$ is wavelength-dependent (Carder et al. 1989) and different wavelength ranges have been used in these studies. Values of $S_{a}$ are not only useful to extrapolate $a_{\mathrm{d}}$ measurements from the UV to the visible range (Bricaud et al. 1981) but also to compare optical characteristics of different types of waters. However, one process that affects $S_{a}$ is CDOM photo-bleaching by solar radiation. Photobleaching rates as well as the production of low molecular weight compounds are proportional to $a_{\mathrm{d}}$ (Kieber et al. 1990). Although the well-mixed water column in Laguna de Rocha did not allow us to compare layers exposed to different UV radiation, the differences in $I_{a}$ and $S_{a}$ between sampling sites may in part have been due to this process. Vodacek et al. (1997) reported an increase in $S_{a}$ values caused by photo-bleaching when CDOM-rich waters were transported towards marine areas. Although our data show that during the open situation $S_{a}$ increased from the tributaries to the lagoon, the DOM input from diffuse sources makes the interpretation of these results rather difficult.

\section{Changes in the underwater optical characteristics arising from ocean-lagoon communication}

Based on the results described above, the dynamics of Laguna de Rocha can be separated into 3 phases that are accompanied by significant shifts in UV penetration (Fig. 6). The first phase is characterized by dominance of freshwater discharge. During this phase, most of the lagoon exhibits homogeneous optical characteristics (Phase I), and the load of dissolved and particulate organic substances (including detritus and phytoplankton) significantly reduce UV and PAR penetration. Phase I lasts until the water level increases, leading to the opening of the sand bar. However, this happens only under the combined action of waves on the seaward side of the sand bar. This is a recurrent situation at Laguna de Rocha, since the local hydrological pattern shows a quasi-periodicity similar to that of the weather systems moving over the western South Atlantic (Smith 1983).

After opening of the sand bar and the subsequent freshwater discharge that can last from few days to several weeks, the ocean intrudes into the lagoon (Phase II), usually under the influence of SE winds (e.g., as observed 1 wk before the first sampling). While a salinity gradient progressively develops, the southern area of the lagoon shifts to a brackish condition while the northern zone remains limnic for a longer period. In this situation, a strong spatial gradi- 


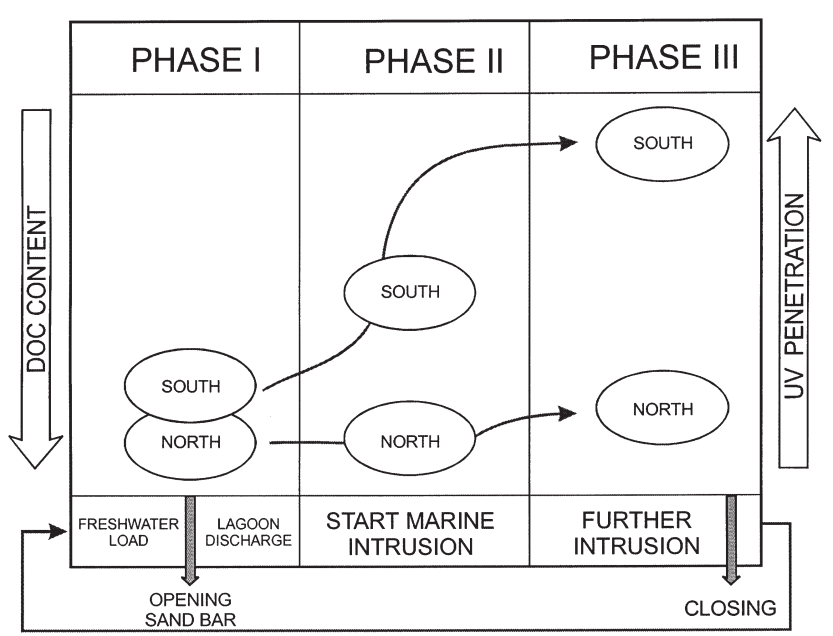

Fig. 6. Hydrological phases in Laguna de Rocha with their respective changes in DOC content and UV penetration. See 'Discussion' for explanations

ent in UV penetration is observed arising from dilution of freshwater rich in dissolved and particulate substances with seawater. In contrast to the situation observed for other lagoons of the region (Abreu et al. 1995), the intrusion of seawater into Laguna de Rocha is generally not accompanied by sediment resuspension in the southern area because sandy sediments are dominant (Conde \& Sommaruga 1999). Moreover, sediment resuspension by tidal action, which has been indicated as an important DOC source for other shallow lagoons (Morales-Zamorano et al. 1991), is not expected to be important because Laguna de Rocha is located on a microtidal coast. Although southeastern winds lasting for several days can push saline waters further north (Phase III), no relevant increase in UV penetration is expected in this zone, because other processes contributing CDOM and particles (e.g., sediment resuspension, freshwater runoff) are dominant.

\section{Implications}

Our results on the dynamics of UV penetration in Laguna de Rocha are relevant to the assessment of the impact of UV-B radiation, because this ecosystem, as well as many other coastal lagoons, is located at a latitude where significant trends in depletion of stratospheric ozone are expected over the next decades (Sze et al. 1989). Nevertheless, other processes, such as a decrease in CDOM export from the catchment during drought periods, that affect not only the underwater UV-B climate but also light in general, may be even more important than the effect of ozone depletion (Schindler et al. 1996, Williamson et al. 1996, Vincent et al. 1998). The rainfall pattern on the southeast coast of South America is tightly coupled to El Niño-Southern Oscillation (ENSO) dynamics (Abreu \& Castello 1997, Genta et al. 1998). In addition, Genta et al. stated that the flow of the rivers draining the eastern basins of South America is expected to decrease in the next few years and to reach a minimum in the 2010s as a consequence of the Amazonian deforestation (see Nobre et al. 1991). Years of reduced freshwater discharge into the coastal Patos Lagoon (Brazil) have been associated with a decline in the allochthonous DOC input and with higher phytoplankton biomass (Knoppers 1996). A concentration of $3.6 \mathrm{mg}$ DOC $^{-1}$ has been suggested as a threshold below which UV may have detectable effects on aquatic communities (Schindler \& Curtis 1997). Low DOC values $\left(\sim 1 \mathrm{mg} \mathrm{l}^{-1}\right)$ were observed in Laguna de Rocha only during the marine intrusion; however, the expected decrease in river flow may further reduce the DOC content of the lagoon.

The wavelengths in the UV-A region have been identified as causing most of the photoinhibition observed in algal photosynthesis (Kim \& Watanabe 1993, Moeller 1994), as well as being potentially damaging to heterotrophic bacteria (Sommaruga et al. 1997) and early life stages of crustacean and fish species (Kuhn et al. 1999). For most parts of Laguna de Rocha (the area between Stns $\mathrm{H}$ and $\mathrm{C}$ ), the high concentration of CDOM and particulate substances reduces the UV penetration to the upper few centimeters of the water column. Nevertheless, the shallowness of the system allows substantial UV-A radiation to penetrate into the water column in these zones (Table 1). Piazena \& Häder (1994) have suggested that even in turbid waters, microalgae populating the top layers of the water column may be affected by UV-B radiation.

One potentially unfavorable situation for planktonic and benthic microalgae is the period of marine intrusion, when UV radiation in the southern area can reach the bottom of the lagoon. In particular, phytoplankton entering with the marine intrusion into the lagoon will suddenly be exposed to considerable fluxes of damaging radiation, especially if the sand bar opens in spring or summer. The structure of the phytoplankton assemblage in the coastal lagoons of the South Atlantic is mainly controlled by hydrological events, being dominated by euryhaline diatoms originating from coastal waters or by limnic cyanobacteria and oligohaline diatoms in the zones influenced by the freshwater load (Abreu et al. 1995, S. Bonilla pers. comm.). According to Abreu \& Castello (1997), the highest phytoplankton abundances in these lagoons are observed after the marine intrusions. The prolonged confinement of phytoplankton in a shallow water column under high UV and PAR fluxes may have photoinhibitory effects similar to those observed in deeper systems, when 
phytoplankton is trapped by diurnal thermoclines close to the surface (Milot-Roy \& Vincent 1994). While in the sea, wind-induced vertical mixing will transport phytoplankton to depths of lower UV irradiance where they can potentially recover (Mallin \& Paerl 1992); in the shallow water column of Laguna de Rocha, this mechanism will be ineffective. Therefore, 2 important questions that need to be addressed in this ecosystem are: how rapidly does phytoplankton acclimate to new light conditions, and how is production affected by UV radiation?

Acknowledgements. We thank Javier Gorga for helping during sampling, Isabelle Laurion for the fluorescence analysis, Roland Psenner for improving the clarity of the manuscript, and 4 anonymous reviewers for valuable suggestions that improved the quality of the manuscript. This research was supported by grants from CONICYT-Uruguay (1099 and 2086), CSIC-Universidad de la República (071), and IFS-Sweden (A/2917-1).

\section{LITERATURE CITED}

Abreu PC, Castello JP (1997) Relationship and function of coastal and marine environments-Estuarine-marine interactions. In: Seeliger U, Odebrecht C, Castello JP (eds) Subtropical convergence environments: the coast and sea in the Southwestern Atlantic. Springer-Verlag, Berlin, p 179-182

Abreu P, Hartmann C, Odebrecht C (1995) Nutrient-rich saltwater and its influence on the phytoplankton of the Patos Lagoon estuary, Southern Brazil. Estuar Coast Shelf Sci 40:219-229

APHA (1995) Standard methods for the examination of water and wastewater. American Public Health Association (APHA/AWWA/WPCF), Washington

Arfi R, Bouvy M (1995) Size, composition and distribution of particles related to wind-induced resuspension in a shallow tropical lagoon. J Plankton Res 17:557-574

Benner R, Strom M (1993) A critical evaluation of the analytic blank associated with DOC measurements by high-temperature catalytic oxidation. Mar Chem 41:153-160

Bricaud A, Morel A, Prieur L (1981) Absorption by dissolved organic matter of the sea (yellow substance) in the UV and visible domains. Limnol Oceanogr 26:43-53

Carder KL, Steward RG, Harvey GR, Ortner PB (1989) Marine humic and fulvic acids: their effects on remote sensing of ocean chlorophyll. Limnol Oceanogr 34:68-81

Coble PG, Brophy MM (1994) Investigation of the geochemistry of dissolved organic matter in coastal waters using optical properties. Ocean Optics 2258:377-389

Conde D, Sommaruga R (1999) A review of the state of limnology in Uruguay. In: Wetzel RG, Gopal B (eds) Limnology in developing countries. SIL/International Science Publishers, New Delhi, p 1-31

Conde D, Bonilla S, Aubriot L, de León R, Pintos W (1999) Comparison of the areal amount of chlorophyll a of planktonic and attached microalgae in a shallow coastal lagoon. Hydrobiologia 408/409:285-291

Cowan JL, Boyton CJ (1996) Sediment-water oxygen and nutrient exchanges along the longitudinal axis of Chesapeake Bay: seasonal patterns, controlling factors and ecological significance. Estuaries 19:562-580
Curtis PJ, Adams HE (1995) Dissolved organic matter quantity and quality from freshwater and saltwater lakes in east-central Alberta. Biogeochemistry 30:59-76

Davies-Colley RJ, Vant WN (1987) Absorption of light by yellow substance in freshwater lakes. Limnol Oceanogr 32: 416-425

Ferrari GM, Dowell MD (1998) CDOM absorption characteristics with relation to fluorescence and salinity in coastal areas of the southern Baltic Sea. Estuar Coast Shelf Sci 47:91-105

Fox LE (1983) The removal of dissolved humic acid during estuarine mixing. Estuar Coast Shelf Sci 16:431-440

Genta JL, Perez G, Mechoso CR (1998) A recent increasing trend in the streamflow of rivers in southeastern South America. J Climate 11:2858-2862

Hodoki Y, Watanabe Y (1998) Attenuation of solar ultraviolet radiation in eutrophic freshwater lakes and ponds. Jpn J Limnol 59:27-37

Jeffrey SW, Humphrey JD (1975) New spectrophotometric equations for determining chlorophylls $\mathrm{a}, \mathrm{b}$ and $\mathrm{c}$ and $\mathrm{c} 1 \mathrm{in}$ higher plants, algae and natural phytoplankton. Biochem Physiol Pflanz 167:191-194

Jerlov NG (1970) Light-general introduction. In: Kinne O (ed) Marine ecology, Vol I. Environmental factors, Part 1. Wiley-Interscience, London, p 95-102

Kieber RJ, Zhou X, Mopper K (1990) Formation of carbonyl compounds from UV-induced photodegradation of humic substances in natural waters: fate of riverine carbon in the sea. Limnol Oceanogr 35:1503-1515

Kim DS, Watanabe Y (1993) The effect of long wave ultraviolet radiation (UV-A) on the photosynthetic activity of natural population of freshwater phytoplankton. Ecol Res 8: $225-234$

Kirchhoff VW, Scuch NJ, Pinheiro DK, Harris J M (1996) Evidence for an ozone hole perturbation at $30^{\circ}$ south. Atmos Environ 30:1481-1488

Kirk JTO (1994a) Light and photosynthesis in aquatic ecosystems. Cambridge University Press, Cambridge

Kirk JTO (1994b) Optics of UV-B radiation in natural waters. Arch Hydrobiol Beih Ergebn Limnol 43:1-16

Kirk JTO, Hargreaves BR, Morris DP, Coffin RB, David B, Frederickson D, Karentz D, Lean DRS, Lesser MP, Madronich S, Morrow JH, Nelson NB, Scully NM (1994) Measurements of UV-B radiation in two freshwater lakes: an instrument intercomparison. Arch Hydrobiol Beih Ergebn Limnol 43:71-99

Knoppers B (1996) Aquatic primary production in coastal lagoons. In: Kjerfve (ed) Coastal lagoons processes. Elsevier, Amsterdam, p 243-286

Kuhn P, Browman H, McArthur B, St-Pierre JF (1999) Penetration of ultraviolet radiation in the waters of the estuary and Gulf of St Lawrence. Limnol Oceanogr 44:710-716

Laurion I, Vincent WF, Lean DRS (1997) Underwater ultraviolet radiation: development of spectral models of northern high latitude lakes. Photochem Photobiol 65:10-114

Mallin MA, Paerl HW (1992) Effects of variable irradiance on phytoplankton productivity in shallow estuaries. Limnol Oceanogr 37:54-62

McKnight DM, Andrews ED, Spaulding SA, Aiken GR (1994) Aquatic fulvic acids in algal-rich Antarctic ponds. Limnol Oceanogr 39:1972-1979

Mechoso CR, Perez-Iribarren G (1992) Streamflow in southeastern South America and the Southern Oscillation. J Climate 5:1535-1539

Milot-Roy V, Vincent WF (1994) UV radiation effects on photosynthesis: the importance of near-surface thermoclines in a subarctic lake. Arch Hydrobiol Beih Ergebn Limnol 43:171-184 
Moeller RE (1994) Contribution of ultraviolet radiation (UV-A, UV-B) to photoinhibition of epilimnetic phytoplankton in lakes of differing UV transparency. Arch Hydrobiol Beih Ergebn Limnol 43:157-170

Morales-Zamorano LA, Cajal R, Orellana E, Jiménez LC (1991) Effect of tidal dynamics on a planktonic community in a coastal lagoon of Baja California, Mexico. Mar Ecol Prog Ser 78:229-239

Moran MA, Sheldon WM, Sheldon JE (1999) Biodegradation of riverine dissolved organic carbon in five estuaries of the Southeastern Unites States. Estuaries 22:55-64

Morris DP, Zagarese $H$, Williamson C, Balseiro E, Hargreaves B, Modenutti B, Moeller R, Queimalinos R (1995) The attenuation of solar UV radiation in lakes and the role of dissolved organic carbon. Limnol Oceanogr 40: 1381-1391

Nieke B, Reuter R, Heuermann R, Wang H, Babin M, Therriault JC (1997) Light absorption and fluorescence properties of chromophoric dissolved organic matter (CDOM), in the St. Lawrence estuary (Case 2 waters). Cont Shelf Res $17: 235-242$

Nobre CA, Sellers PJ, Shukla J (1991) Amazonian deforestation and regional climate change. J Climate 4:957-988

Orce VL, Helbling EW (1997) Latitudinal UVR-PAR measurements in Argentina: extent of the 'ozone hole'. Global Planet Change 15:113-121

Piazena H, Häder DP (1994) Penetration of solar UV irradiation in coastal lagoons of the Southern Baltic Sea and its effect on phytoplankton communities. Photochem Photobiol 60:463-469

Piazena H, Häder DP (1997) Penetration of solar UV and PAR into different waters of the Baltic Sea and remote sensing of phytoplankton. In: Häder DP (ed) The effects of ozone depletion on aquatic ecosystems. RG Landes Company, Austin, TX, p 45-96

Schindler DW, Curtis PJ (1997) The role of DOC in protecting freshwaters subjected to climatic warming and acidification from UV exposure. Biogeochemistry 36:1-8

Schindler DW, Curtis PJ, Parker BR, Stainton MP (1996) Consequences of climate warming and lake acidification for UV-B penetration in North American boreal lakes. Nature 379:705-708

Editorial responsibility: Howard Browman (Contributing Editor), Storebø, Norway
Scully NM, Lean DRS (1994) The attenuation of ultraviolet radiation in temperate lakes. Arch Hydrobiol Beih Ergebn Limnol 43:135-144

Sharp JH, Culberson CH, Church TM (1982) The chemistry of the Delaware estuary: general considerations. Limnol Oceanogr 60:328-332

Smith NP (1983) Tidal and low-frequency net displacement in a coastal lagoon. Estuaries 6:180-189

Smith REH, Furgal JA, Charlton MN, Greenberg BM, Hiriart V, Marwood C (1999) Attenuation of ultraviolet radiation in a large lake with low dissolved organic matter concentrations. Can J Fish Aquat Sci 56:1351-1361

Sommaruga R, Psenner R (1997) Ultraviolet radiation in a high mountain lake of the Austrian Alps: air and underwater measurements. Photochem Photobiol 65:957-963

Sommaruga R, Obernosterer I, Herndl G, Psenner R (1997) Inhibitory effect of solar radiation on thymidine and leucine incorporation by freshwater and marine bacterioplankton. Appl Environ Microbiol 63:4178-4184

Sze ND, Ko KW, Weisenstein DK, Rodriguez JM, Stolarski RS, Schoeberl MR (1989) Antarctic ozone hole: possible implications for ozone trends in the southern hemisphere. J Geophys Res 94:11521-11528

Vincent WF, Laurion I, Pienitz R (1998) Arctic and Antarctic lakes as global indicators of global change. Ann Glaciol 27:691-696

Vodacek A, Blough NV, DeGranpre MD, Peltzer ET, Nelson RK (1997) Seasonal variation of CDOM and DOC in the Middle Atlantic Bight: terrestrial inputs and photooxidation. Limnol Oceanogr 42:674-686

Williamson CE, Stemberger RS, Morris DP, Frost TM, Paulsen SG (1996) Ultraviolet radiation in North American lakes: attenuation estimates from DOC measurements and implications for plankton communities. Limnol Oceanogr 41: 1024-1034

Xenoupoulos MA, Bird D (1997) Effects of acute exposure to hydrogen peroxide on the production of phytoplankton and bacterioplankton in a mesohumic lake. Photochem Photobiol 66:471-478

Yoro SC, Panagiotopoulos C, Sempéré R (1999) Dissolved organic carbon contamination induced by filters and storage bottles. Wat Res 33:1956-1959

Submitted: November 5, 1999; Accepted: June 8, 2000

Proofs received from author(s): October 18, 2000 